\title{
Kemampuan Komunikasi Matematis dalam Menyelesaikan Circle Problem Berdasarkan Self-Confidence Siswa SMP
}

\author{
Wasilatul Murtafiah $^{1 *}$, Reza Kusuma Setyansah ${ }^{2}$, Dhea Alvita Nurcahyani ${ }^{3}$ \\ 1,2,3Program Studi Pendidikan Matematika, Universitas PGRI Madiun \\ *wasila.mathedu@unipma.ac.id.
}

\begin{abstract}
Abstrak
Sebagai bagian dari keterampilan abad 21, komunikasi merupakan kemampuan yang penting dimiliki oleh siswa. Komunikasi matematis siswa cenderungg rendah, salah satunya dipengaruhi oleh self-confidence siswa. Untuk itu tujuan penelitian ini mendeskripsikan kemampuan komunikasi matematis dalam menyelesaikan circle problem berdasarkan self-confidence siswa. Penentuan subjek menggunakan teknik purposing sampling yaitu dari 36 siswa kelas VIII SMP di Madiun, Jawa Timur, Indonesia, diperoleh 2 subjek yang terdiri dari 1 subjek dengan self-confidence tinggi (SCT) dan 1 subjek dengan self-confidence rendah (SCR). Pendekatan deskriptif kualitatif digunakan dalam penelitian ini. Tes dan wawancara digunakan sebagai teknik pengumpulan data. Data dianalisis melalui reduksi, penyajian, serta penarikan kesimpulan. Hasil penelitian ini meliputi: SCT mampu sedangkan SCR kurang mampu memenuhi indikator kemampuan komunikasi matematis baik secara tulis maupun lisan pada tahap memahami masalah, melaksanakan rencana, dan memeriksa kembali; dan SCT mampu memenuhi indikator komunikasi matematis baik tulis dan lisan, sedangkan SCR kurang mampu memenuhi indikator komunikasi matematis tulis tetapi mampu secara lisan pada tahap merencanakan penyelesaian. Tingkat self-confidence siswa membedakan kemampuan komunikasi matematisnya dalam menyelesaikan masalah. Dengan demikian, perlunya seorang guru merancang masalah yang sesuai agar dapat melatih kemampuan komunikasi matematis siswa dengan self-confidence rendah.
\end{abstract}

Kata Kunci: circle problem, komunikasi matematis, self-confidence

\begin{abstract}
As part of 21st-century skills, communication is an essential skill for students. Students' mathematical communication tends to below, one of which is influenced by students' self-confidence. For this reason, the purpose of this study is to describe the mathematical communication skills in solving circle problems based on students' self-confidence. Determining the subject using purposive sampling technique, namely from 36 students of class VIII SMP in Madiun, East Java, Indonesia, obtained two subjects with high self-confidence (SCT) and one subject with low self-confidence (SCR). A qualitative descriptive approach was used in this study. Tests and interviews were used as data collection techniques. Data were analyzed through reduction, presentation, and concluding. The results of this study include: SCT is capable while SCR is less able to meet the indicators of mathematical communication skills both in writing and orally at the stages of understanding problems, implementing plans, and checking back; and SCT can meet mathematical communication indicators both written and oral, while SCR is less able to meet written mathematical communication indicators but can verbally at the stage of planning completion. The level of self-confidence of students differentiates their mathematical communication skills in solving problems. Thus, a teacher needs to design an appropriate question to train students' mathematical communication skills with low self-confidence.
\end{abstract}

Keywords: circle problem, mathematical communication, self-confidence 


\section{Pendahuluan}

Salah satu kompetensi yang harus disiapkan untuk menghadapi tantang zaman adalah komunikasi, yang termuat dalam keterampilan abad 21, 4C's yaitu communication, collaboration, critical thinking dan creativity (Voogt \& Roblin, 2012; Scott, 2015; Nganga, 2019). Kemampuan komunikasi juga menjadi tuntutan Kurikulum 2013, bahwa matematika yang abstrak harus mampu disajikan dalam permasalahan konkret sehingga siswa akan dituntut berpikir kreatif serta mampu mengkomunikasikannya (Majid, 2015). Kegiatan siswa dalam mengkomunikasikan pemecahan masalah dalam pembelajaran matematika merupakan kompetensi yang sejalan dengan NCTM (2000). Kemampuan siswa dalam mengkomunikasikan pemecahan masalah penting dikembangkan untuk menghadapi perkembangan zaman. Kemampuan siswa dalam berkomunikasi dan menyelesaikan masalah merupakan bagian dari keterampilan abad 21 (Letwinsky, 2017).

Komunikasi merupakan proses yang esensial dalam pembelajaran matematika. Siswa dapat mengatur, merenungkan dan mengklarifikasi gagasan, hubungan, pemikiran matematis dan argumen matematis melalui komunikasi (Vale \& Barbosa, 2017). Melalui komunikasi yang baik dalam pembelajaran, siswa dapat memperoleh pemahaman yang lebih baik tentang dasardasar konseptual matematika dan menjadi pemecah masalah yang lebih baik (Brenner, 1998). Nurlaila, Sariningsih, \& Maya (2018) menyatakan bahwa komunikasi matematis adalah cara untuk mengungkapkan suatu ide matematis secara lisan ataupun tertulis dalam bentuk gambar, aljabar ataupun diagram. Salah satu ide matematis yang dikomunikasikan siswa pada pembelajaran matematika adalah lingkaran. Dalam lingkaran terdapat unsur-unsur yang terdiri dari busur, tali busur, jari-jari, diameter, spotema, juring, dan tembereng (As'ari, Tohir, Valentino, Imron, \& Taufiq, 2017). Materi lingkaran ini penting diberikan kepada siswa karena dalam kehidupan sehari-hari terdapat permasalahan yang dapat diselesaikan dengan menggunakan konsep lingkaran.

Berdasarkan hasil studi awal di salah satu SMP di Madiun, Jawa Timur, sebagaian besar siswa kesulitan mengkomunikasikan pemecahan masalah baik tertulis maupun lisan ketika diberikan masalah matematika yang berkaitan dengan lingkaran (Murtafiah, 2009). Siswa tampak ragu menuliskan penyelesaiannya karena banyak coretan pada jawaban tertulisnya. Ketika diminta menjelaskan pekerjaannya secara lisan, beberapa siswa tampak malu-malu dan kurang tepat dalam menyebutkan simbol atau lambang lingkaran pada jsawabannya. Kondisi tersebut sejalan dengan Ramadhan dan Minarti (2018) dan Noviyana, Dewi, dan Rochmad (2019) yang menyatakan bahwa masih rendahnya kemampuan komunikasi matematis siswa. 
Fakta ini juga didukung oleh sebuah laporan studi video TIMSS (Ragatz, 2010) tentang capaian siswa yang menunjukkan jumlah kata yang diucapkan oleh siswa umumnya hanya 194 kata, yang menandakan rendahnya komunikasi siswa. Penulis menduga bahwa rendahnya komunikasi siswa tersebut salah satunya disebabakan oleh kurangnya kepercayaan diri/selfconfidence siswa pada saat pembelajaran. Ini juga sejalan dengan Noviyana et al. (2019) yang menyatakan adanya keterkaitan antara kemampuan komunikasi matematis dan self-confidence.

Self-confidence merupakan percaya terhadap kemampuan sendiri dalam menyelesaikan tindakan sesuai dengan tuntutan tugas (Bandura, 1994; Hendriana, 2014; Martyanti, 2016). Seseorang yang percaya diri akan yakin dengan kemampuannya menyelesaikan suatu pekerjaan dan masalah (Lie, 2003; Agustyaningrum \& Widjajanti, 2013; Nurkholifah, Toheri, \& Winarso, 2018). Self-confidence siswa dapat ditandai dengan keyakinannya seperti dalam menyelesaikan tugas-tugas matematika di sekolah serta mengkomunikasikan tugas matematika atau kemampuan komunikasi matematis. Siswa dapat mengorganisasikan berpikir matematisnya baik lisan maupun tulisan serta memberikan respon yang tepat antar siswa dalam proses pembelajaran melalui komunikasi matematis (Umar, 2012).

Penelitian dan literature review tentang komunikasi matematis telah laporkan oleh beberapa penulis (Asikin \& Junaedi, 2013; Alhaddad, Kusumah, Sabandar, \& Dahlan, 2015; Rizqi, Suyitno, \& Sudarmin, 2016; Murtafiah, 2016; Nurlaila et al., 2018; Ramadhan \& Minarti, 2018; Noviyana et al., 2019). Asikin dan Junaedi (2013) meneliti tentang komunikasi matematis siswa dalam setting pembelajaran realistic matematics education (RME). Rizqi, Suyitno, dan Sudarmin (2016) meneliti kemampuan komunikasi matematis siswa dalam blended learning tergolong baik pada materi transformasi berdasarkan kepercayaan diri siswa. Alhaddad, Kusumah, Sabandar, dan Dahlan (2015) telah menyelidiki, membandingkan, dan mendiskripsikan tentang pencapaian dan peningkatan kemampuan komunikasi matematis berdasarkan kategori kemampuan awal matematis mahasiswa. Murtafiah (2016) telah meneliti kemampuan komunikasi matematis mahasiswa calon guru matematika dalam menyelesaikan masalah persamaan diferensial berdasarkan gender. Nurlaila et al. (2018) meneliti tentang kemampuan komunikasi matematis siswa kelas VIII SMP mengenai bangun ruang sisi datar. Ramadhan dan Minarti (2018) telah meneliti komunikasi matematis siswa SMP dalam menyelesaikan soal lingkaran. Noviyana et al. (2019) melakukan literature review tentang analisis kemampuan komunikasi matematis siswa ditinjau dari self-confidence.

Hasil penelitian dan literature review di atas menunjukkan bahwa masih belum adanya penelitian tentang komunikasi matematis siswa dalam menyelesaikan masalah lingkaran/circle 
problem ditinjau dari self-confidence siswa. Komunikasi matematis siswa pada penelitian ini dilihat berdasarkan indikator menuliskan dan menjelaskan secara lisan ide, situasi, relasi matematika, serta representasi dalam menyatakan konsep maupun hasil penyelesaian (Brenner, 1998), pada setiap langkah pemecahan masalah Polya. Dengan demikian, perlunya dilakukan penelitian yang bertujuan mendeskripsikan komunikasi matematis siswa dalam menyelesaikan circle problem baik secara tertulis maupun lisan pada siswa dengan self-confidence tinggi dan rendah, sehingga dapat digunakan sebagai dasar guru dalam merancang pembelajaran yang lebih sesuai.

\section{Metode}

Deskriptif kualitatif merupakan pendekatan dalam penelitian ini guna mendeskripsikan kemampuan komunikasi matematis dalam menyelesaikan masalah lingkaran (circle problem) berdasarkan self-confidence siswa. Self-confidence siswa diukur dengan menggunakan angket yang diadaptasi dari Lauster (2003) dengan hasil uji validitas, sebanyak 48 butir angket dinyatakan valid dengan masing-masing $\mathrm{r}$ hitung $>\mathrm{r}$ tabel $=1,677$ dan reliabilitas sangat tinggi dengan korelasi product moment $\mathrm{r}_{\mathrm{xy}}=0,893$ (Sumarna, 2009). Pengelompokan self-confidence dilakukan dengan menggunakan rumus distribusi normal menurut Budiyono (2011) yaitu kategori tinggi jika skor > (Rerata+Simpangan Baku), kategori sedang jika skor antara (RerataSimpangan Baku) sampai (Rerata+Simpangan Baku) dan kategori rendah jika skor < (RerataSimpangan Baku). Hasil perhitungan dari data kepercayaan diri, diperoleh rerata sebesar 130,7 dan simpangan baku sebesar 21,7.

Tabel 1. Data Self-confidence Siswa

\begin{tabular}{lccc}
\hline \multicolumn{1}{c}{ Kategori } & Rentang Skor & Jumlah & Persentase \\
\hline Self-confidence tinggi & Skor $\geq 152,4$ & 4 & $11,1 \%$ \\
\hline Self-confidence sedang & $190,0<$ Skor $<152,4$ & 27 & $75 \%$ \\
\hline Self-confidence rendah & Skor $\leq 190,0$ & 5 & $13,9 \%$ \\
\hline
\end{tabular}

Tabel 1. Menunjukkan kategori siswa terbanyak adalah siswa dengan self-confidence sedang yaitu $27(75 \%)$ siswa. Untuk melihat perbedaan yang signifikan maka subjek yang dipilih dalam penelitian ini merupakan siswa dengan self-confidence tinggi dan rendah. Subjek dalam penelitian ini diambil dari 36 siswa kelas VIII SMP di Madiun, Jawa Timur, Indonesia. Teknik pengambilan subjek dalam penelitian ini menggunakan purposing sampling yaitu teknik pengambilan sampel sumber data dengan pertimbangan tertentu (Sugiyono, 2013). Pemilihan subjek penelitian didasarkan pada hasil pengelompokan self-confidence tinggi dan rendah. Peneliti berdiskusi dengan guru matematika di kelas tersebut untuk memberikan saran 
mengenai subjek yang akan dipilih. Berdasarkan hasil pengelompokan dan pertimbangan dari guru maka subjek yang dipilih adalah 1 siswa dengan self-confidence tinggi (SCT) dan 1 siswa dengan self-confidence rendah (SCR), yang kemudian dilihat kemampuan komunikasi matematisnya dalam menyelesaikan masalah.

Tes tertulis dan pedoman wawancara digunakan untuk pengumpulan data pada penelitian ini. Tes tertulis digunakan untuk mengetahui kemampuan komunikasi matematis tertulis siswa. Pedoman wawancara digunakan untuk mengetahui kemampuan komunikasi matematis lisan siswa. Instrumen tes tertulis dan pedoman wawancara yang digunakan dalam penelitian ini divalidasi konstruk oleh 3 validator ( 2 dosen pendidikan matematika dan 1 guru matematika SMP). Hasil validasi tes tulis dan pedoman wawancara mendapatkan kriteria validitas secara berturut-turut $85,8 \%$ dengan tingkat validitas sangat valid dan $82,3 \%$ dengan tingkat validitas cukup valid menurut Akbar (2013), sehingga dapat digunakan sebagai instrumen pada penelitian ini. Instrumen soal tes tulis yang telah divalidasi konstruk dan digunakan pada penelitian ini disebut sebagai masalah lingkaran (circle problem) dengan indikator pada Tabel 2 sebagai berikut.

Tabel 2. Indikator Soal Tes (Circle Problem)

\begin{tabular}{|c|c|c|c|}
\hline $\begin{array}{c}\text { Kompetensi } \\
\text { Dasar }\end{array}$ & $\begin{array}{c}\text { Indikator } \\
\text { Pencapaian } \\
\text { Kompetensi (IPK) }\end{array}$ & $\begin{array}{c}\text { Level } \\
\text { Kognitif }\end{array}$ & Soal Tes (Circle Problem) \\
\hline $\begin{array}{l}\text { Menyelesaikan } \\
\text { masalah } \\
\text { kontekstual } \\
\text { yang berkaitan } \\
\text { dengan } \\
\text { keliling dan } \\
\text { luas lingkaran }\end{array}$ & $\begin{array}{l}\text { Menyelesaikan } \\
\text { masalah kontekstual } \\
\text { yang berkaitan } \\
\text { dengan luas daerah } \\
\text { lingkaran }\end{array}$ & $\mathrm{C} 4$ & $\begin{array}{l}\text { Suatu pabrik yang memproduksi makanan } \\
\text { ringan membuat biskuit berbentuk } \\
\text { lingkaran padat dengan diameter } 5 \mathrm{~cm} \text {. } \\
\text { Pabrik tersebut ingin membuat variasi } \\
\text { produk yaitu membuat biskuit dengan } \\
\text { ketebalan yang sama namun bentuk berbeda } \\
\text { berupa juring lingkaran dengan sudut pusat } \\
90^{\circ} \text {. Agar bahan produksi yang digunakan } \\
\text { sama dengan biskuit yang berbentuk } \\
\text { lingkaran, tentukan diameter biskuit } \\
\text { berbentuk juring lingkaran yang dibuat oleh } \\
\text { pabrik tersebut! }\end{array}$ \\
\hline
\end{tabular}

Selanjutnya, untuk mendeskripsikan kemampuan komunikasi matematis siswa dalam menyelesaikan circle problem digunakan indikator komunikasi matematis menurut Brenner (1998) pada setiap langkah pemecahan masalah menurut Polya (1973) yang dapat dilihat pada Tabel 3. 
Tabel 3. Indikator Komunikasi Matematis Tulis dan Lisan

\begin{tabular}{|c|c|c|c|c|c|}
\hline \multirow[b]{2}{*}{ No. } & \multirow[b]{2}{*}{$\begin{array}{c}\text { Komunikasi } \\
\text { Matematis }\end{array}$} & \multicolumn{4}{|c|}{ Indikator Komunikasi Matematis dalam Menyelesaikan Masalah } \\
\hline & & Memahami masalah & $\begin{array}{c}\text { Merencanakan } \\
\text { penyelesaian } \\
\text { masalah }\end{array}$ & $\begin{array}{c}\text { Melaksanakan } \\
\text { rencana } \\
\text { penyelesaian }\end{array}$ & $\begin{array}{c}\text { Memeriksa } \\
\text { kembali hasil } \\
\text { penyelesaian }\end{array}$ \\
\hline 1. & Tulis & $\begin{array}{l}\text { Siswa mampu } \\
\text { menuliskan apa yang } \\
\text { diketahui dan ditanyakan } \\
\text { dari soal berupa ide } \\
\text { (lambang, notasi, } \\
\text { persamaan matematika), } \\
\text { situasi, relasi serta } \\
\text { representasi yang } \\
\text { berkaitan dengan } \\
\text { lingkaran }\end{array}$ & $\begin{array}{l}\text { Siswa mampu } \\
\text { menuliskan } \\
\text { rencana } \\
\text { pemecahan } \\
\text { masalah yang } \\
\text { berkaitan dengan } \\
\text { lingkaran dalam } \\
\text { bentuk aljabar atau } \\
\text { representasi } \\
\text { lainnya }\end{array}$ & $\begin{array}{l}\text { Siswa mampu } \\
\text { menuliskan } \\
\text { langkah-langkah } \\
\text { dari rencana yang } \\
\text { sudah dibuat untuk } \\
\text { menyelesaikan } \\
\text { masalah lingkaran } \\
\text { dalam bentuk } \\
\text { aljabar atau } \\
\text { representasi lainnya }\end{array}$ & $\begin{array}{l}\text { Siswa mampu } \\
\text { menuliskan } \\
\text { hasil dan } \\
\text { kesimpulan dari } \\
\text { pemecahan } \\
\text { masalah } \\
\text { lingkaran dalam } \\
\text { bentuk } \\
\text { pernyataan }\end{array}$ \\
\hline 2. & Lisan & $\begin{array}{l}\text { Siswa mampu } \\
\text { menjelaskan apa yang } \\
\text { diketahui dan ditanyakan } \\
\text { dari soal dengan } \\
\text { menyatakan/menjelaskan } \\
\text { ide (istilah matematika), } \\
\text { situasi, relasi } \\
\text { matematika yang } \\
\text { berkaitan dengan } \\
\text { lingkaran }\end{array}$ & $\begin{array}{l}\text { Siswa mampu } \\
\text { menjelaskan } \\
\text { rencana } \\
\text { pemecahan } \\
\text { masalah yang } \\
\text { berkaitan dengan } \\
\text { istilah pada konsep } \\
\text { lingkaran }\end{array}$ & $\begin{array}{l}\text { Siswa mampu } \\
\text { menjelaskan } \\
\text { langkah-langkah } \\
\text { dari rencana yang } \\
\text { sudah dibuat untuk } \\
\text { menyelesaikan } \\
\text { masalah lingkaran } \\
\text { dengan istilah serta } \\
\text { lambang/simbol } \\
\text { pada konsep } \\
\text { lingkaran }\end{array}$ & $\begin{array}{l}\text { Siswa mampu } \\
\text { menjelaskan } \\
\text { hasil dan } \\
\text { kesimpulan dari } \\
\text { pemecahan } \\
\text { masalah } \\
\text { lingkaran }\end{array}$ \\
\hline
\end{tabular}

Teknik analisis data pada penelitian ini meliputi 3 tahap antara lain: (1) reduksi data tes tulis dan wawancara berdasarkan indikator kemampuan komunikasi matematis siswa SCT dan SCR, (2) pemaparan data tes tulis dan wawancara berdasarkan indikator kemampuan komunikasi matematis siswa dengan self-confidence tinggi dan rendah (SCT dan SCR), serta (3) penarikan kesimpulan tentang kemampuan komunikasi matematis siswa. Reduksi data dilakukan untuk mempermudah peneliti dalam memilih data yang sesuai. Pemaparan data dilakukan agar data yang disajikan lebih mudah dipahami. Setelah itu dilakukan penarikan kesimpulan tentang kemampuan komunikasi matematis siswa dalam menyelesaiakan circle problem pada SCT dan SCR.

\section{Hasil Penelitian}

Penelitian dilakukan dengan memberikan tes tulis berupa circle problem dan wawancara pada subjek SCT dan SCR. Data tes tulis dan wawancara terhadap subjek SCT dan SCR selanjutnya direduksi sesuai dengan indikator kemampuan matematis siswa pada Tabel 3. Setelah dilakukan reduksi, data dipaparkan berdasarkan indikator kemampuan komunikasi matematis siswa untuk selanjutnya dilakukan penarikan kesimpulan mengenai kemampuan komunikasi matematis dalam menyelesaikan circle problem berdasarkan self-confidence siswa. 
Berikut ini dipaparkan secara berturut-turut kemampuan komunikasi matematis dalam menyelesaikan circle problem oleh subjek SCT dan SCR.

\section{Kemampuan Komunikasi Matematis SCT}

Kemampuan komunikasi matematis pada tahap memahami masalah, SCT mampu menuliskan apa yang diketahui dan ditanyakan seperti tampak pada Gambar 1.

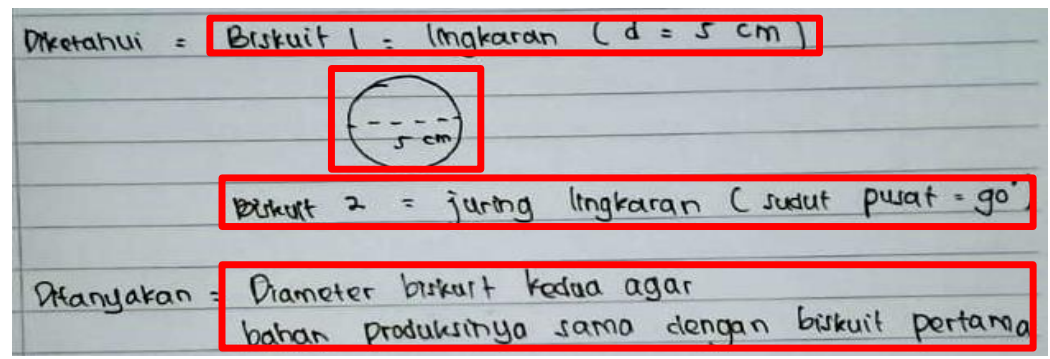

Gambar 1. Komunikasi Matematis SCT dalam Memahami Masalah

SCT menuliskan apa yang diketahui berupa ide matematika yaitu lambang lingkaran, diameter dan juring. SCT menghubungkan situasi biskuit pada masalah dengan ide matematika yaitu berbentuk lingkaran. Relasi yang dinyatakan oleh SCT adalah tanda sama dengan (=) untuk menyatakan biskuit 1 berbentuk lingkaran, biskuit 2 berbentuk juring dengan sudut pusat sebesar $90^{\circ}$. SCT menuliskan yang ditanyakan berdasarkan masalah yang diberikan. SCT memenuhi indikator dapat memahami circle problem yang diberikan dengan menuliskan yang diketahui dan ditanyakan berupa ide (lambang, notasi, persamaan matematika), situasi, relasi serta representasi yang berkaitan dengan lingkaran. Berdasarkan hasil wawancara, SCT juga memenuhi indikator kemampuan komunikasi matematis lisan yaitu dapat menyatakan ide (istilah), situasi, dan relasi matematika dengan menjelaskan secara lisan informasi apa yang diketahui dan ditanya pada circle problem. SCT menjelaskan bahwa "yang diketahui adalah sebuah pabrik akan membuat dua biskuit, dimana biskuit pertama berbentuk lingkaran dengan diameter lima centimeter dan akan membuat satu lagi dengan bentuk juring lingkaran yang memiliki sudut pusat sembilan puluh derajat. Lalu yang ditanyakan adalah diameter biskuit kedua agar bahan produksinya sama dengan biskuit pertama”.

Kemampuan komunikasi matematis pada tahap merencanakan penyelesaian masalah, SCT dapat merencanakan pemecahan dengan menuliskan lambang luas lingkaran (biskuit 1) dengan L biskuit 1, luas juring lingkaran (biskuit 2) dengan L juring biskuit 2, dan persamaan L juring biskuit 2 dengan L biskuit 1 seperti pada Gambar 2. 


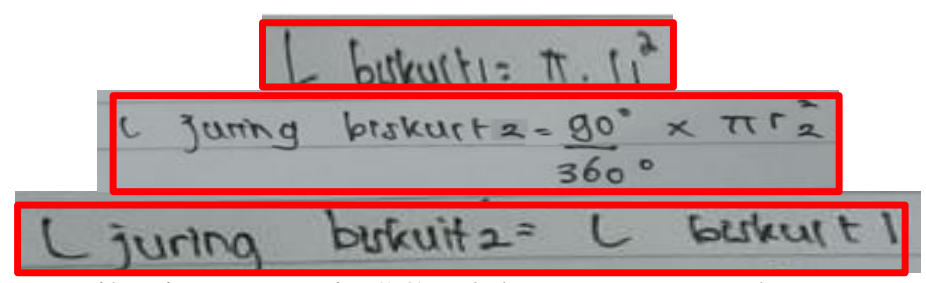

Gambar 2. Komunikasi Matematis SCT dalam Merencanakan Pemecahan Masalah

SCT memenuhi indikator kemampuan komunikasi matematis tulis dalam merencanakan penyelesaian yaitu dapat menuliskan rencana pemecahan masalah yang berkaitan dengan lingkaran dalam bentuk aljabar atau representasi tulis. Berdasarkan paparan hasil wawancara, SCT memenuhi indikator kemampuan komunikasi matematis lisan dalam merencanakan pemecahan yaitu dapat menjelaskan rencana pemecahan masalah dengan menggunakan istilah luas, juring lingkaran, serta jari-jari seperti pada kutipan, "pertama saya mencari luas lingkaran karena biskuit pertama berbentuk lingkaran, setelah itu saya mencari luas juring untuk biskuit kedua bu. Kalau sudah ketemu semua saya buat persamaan dari luas juring dan luas lingkaran tadi untuk mencari jari-jari biskuit kedua".

Kemampuan komunikasi matematis pada tahap melaksanakan rencana, SCT mampu menyelesaikan masalah dengan cara menjabarkan prosedur langkah-langkah penyelesaian seperti tampak pada Gambar 3.

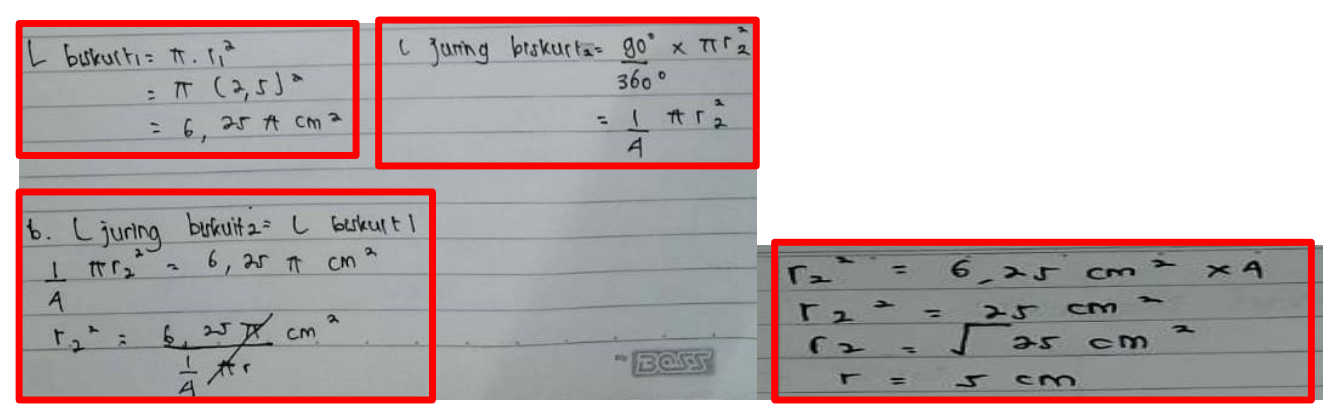

Gambar 3. Kemampuan Komunikasi Matematis SCT dalam Melaksanaakan Rencana

SCT memenuhi indikator kemampuan komunikasi matematis tulis yaitu menuliskan langkah-langkah dari rencana yang sudah dibuat untuk menyelesaikan masalah lingkaran dalam bentuk aljabar atau representasi lainnya. Subjek SCT menuliskan prosedur langkah-langkah dalam bentuk aljabar seperti menghitung luas lingkaran (biskuit 1) dengan menggunakan rumus $L=\pi r^{2}$ dan luas juring biskuit 2 dengan menggunakan rumus $L=\frac{<\text { pusat juring }}{<\text { pusat lingkaran }} \pi r^{2}$. Berdasarkan paparan hasil wawancara, SCT memenuhi indikator kemampuan komunikasi matematis lisan yaitu dapat menjelaskan langkah-langkah dari rencana yang sudah dibuat untuk menyelesaikan masalah lingkaran dengan istilah serta lambing/simbol pada konsep lingkaran. SCT menjelaskan "saya mencari luas lingkaran karena biskuit pertama berbentuk lingkaran, 
dengan rumus phi kali $r$ kuadrat, yang hasilnya enam koma dua puluh lima phi centimeter kuadrat. Setelah itu saya mencari luas juring untuk biskuit kedua bu. Karena sudut pusatnya sembilan puluh derajat maka sembilan puluh derajat per tiga ratus enam puluh derajat dikali phi $r$ dua kuadrat sama dengan seperempat phi $r$ dua kuadrat...”.

SCT mampu memeriksa kembali hasil yang diperoleh. SCT memenuhi indikator kemampuan komunikasi matematis tulis yaitu menuliskan hasil dan kesimpulan dari pemecahan masalah lingkaran seperti pada Gambar 4.

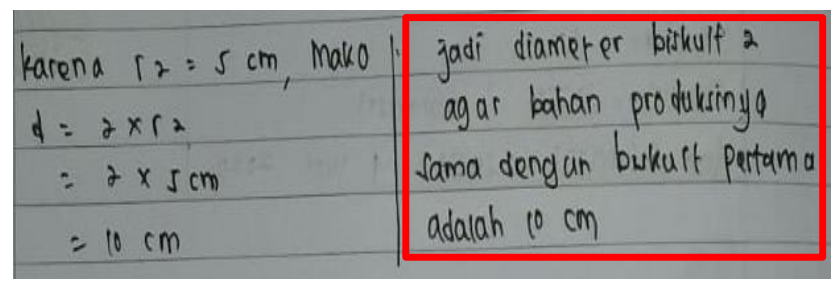

Gambar 4. Komunikasi Matematis SCT dalam Memeriksa Kembali Penyelesaian

SCT menghubungkan langkah-langkah penyelesaian untuk menarik kesimpulan dan memperoleh hasil penyelesaian masalah tersebut dengan menuliskan pernyataan "Jadi diameter biskuit 2 agar bahan produksinya sama dengan biskuit pertama adalah $10 \mathrm{~cm}$ ” pada akhir penyelesaian. Berdasarkan paparan hasil wawancara, SCT memenuhi indikator mampu menjelaskan hasil dan kesimpulan dari pemecahan masalah lingkaran. SCT menjelaskan bahwa "karena jari-jarinya lima centimeter maka diameter untuk biskuit kedua adalah $10 \mathrm{~cm}$. Jadi, diameter biskuit kedua agar bahan produksinya sama dengan biskuit pertama adalah 10 cm”.

\section{Kemampuan Komunikasi Matematis SCR}

Kemampuan komunikasi matematis pada tahap memahami masalah, SCR kurang lengkap dalam menuliskan apa yang diketahui dan apa yang ditanyakan seperti tampak pada Gambar 5 .

\begin{tabular}{|c|c|}
\hline \multirow[t]{2}{*}{ Diretahui } & Biskuit 1 lingkaran ( d. $s(m)$ \\
\hline & Biskut 2 - Juing lingkaran (sudut pusat $90^{\circ}$ ) \\
\hline Ditanyakan & ai ameter bickuit 2? \\
\hline
\end{tabular}

Gambar 5. Komunikasi Matematis SCR dalam Memahami Masalah

SCR menuliskan apa yang diketahui berupa ide matematika yaitu menghubungkan situasi yaitu biskuit pada masalah dengan ide matematika yaitu berbentuk lingkaran. SCR belum bisa merepresentasikan dalam bentuk gambar apa yang diketahui. SCR tampak mencoret lambang diameter dan ukurannya, serta kurang lengkap dalam menuliskan apa yang ditanyakan, karena tidak memberikan representasi berupa gambar lingkaran (pada Gambar 5). SCR kurang memenuhi indikator dalam memahami circle problem yang diberikan dengan menuliskan apa 
yang diketahui dan ditanyakan berupa ide (lambang, notasi, persamaan matematika), situasi, relasi, dan belum menyajikan representasi lingkaran berbentuk gambar. Berdasarkan paparan hasil wawancara, SCR kurang memenuhi indikator kemampuan komunikasi matematis dalam memahami masalah. SCR mampu menjelaskan apa yang diketahui pada soal dengan menyebutkan ide (istilah), situasi dan relasi matematika, namun kurang lengkap dalam menjelaskan apa yang ditanyakan, seperti tampak pada kutipaan wawancara, "yang diketahui adalah biskuit pertama berbentuk lingkaran dengan diameter lima centimeter dan biskuit kedua dengan bentuk juring lingkaran yang memiliki sudut pusat sembilan puluh derajat. Lalu yang ditanyakan adalah diameter biskuit kedua. Sudah itu bu...”.

Pada tahap merencanakan penyelesaian masalah, SCR merencanakan pemecahan masalah dengan menuliskan luas lingkaran biskuit, luas juring lingkaran, dan membuat persamaan luas juring lingkaran 2 dengan lingkaran 1 seperti tampak pada Gambar 6 .

Whas lingkaran biskuit. $\pi r_{1}^{2}$
Chas juring lingkaran $=\frac{90^{\circ}}{360^{\circ}} \times \pi r_{2}^{2}$
thas furing lingkaran $2=\&$ lingkaran i

Gambar 6. Komunikasi Matematis SCR dalam Merencanakan Pemecahan Masalah

SCT kurang memenuhi indikator kemampuan komunikasi matematis tulis dalam merencanakan penyelesaian. SCR menuliskan luas lingkaran biskuit tetapi belum menuliskan biskuit 1, begitu juga pada luas juring lingkaran belum dituliskan biskuit 2. Pada persamaan juga kurang jelas dalam penulisannya yaitu pada ruas kiri luas juring lingkaran 2 tetapi pada ruas kanan hanya lingkaran saja dan tidak dituliskan luas lingkaran 1. Berdasarkan paparan hasil wawancara, SCT memenuhi indikator kemampuan komunikasi matematis lisan dalam merencanakan pemecahan yaitu dapat menjelaskan rencana pemecahan masalah dengan menggunakan istilah luas, juring lingkaran serta diameter seperti pada kutipan, "pertama saya mencari luas lingkaran karena biskuit pertama berbentuk lingkaran. Setelah itu saya mencari luas juring untuk biskuit kedua bu, kemudian mencari diameter biskuit kedua".

Kemampuan komunikasi matematis pada tahap melaksanakan rencana pemecahan masalah, SCR mampu menyelesaikan masalah dengan menuliskan langkah-langkah penyelesaian seperti tampak pada Gambar 7. 


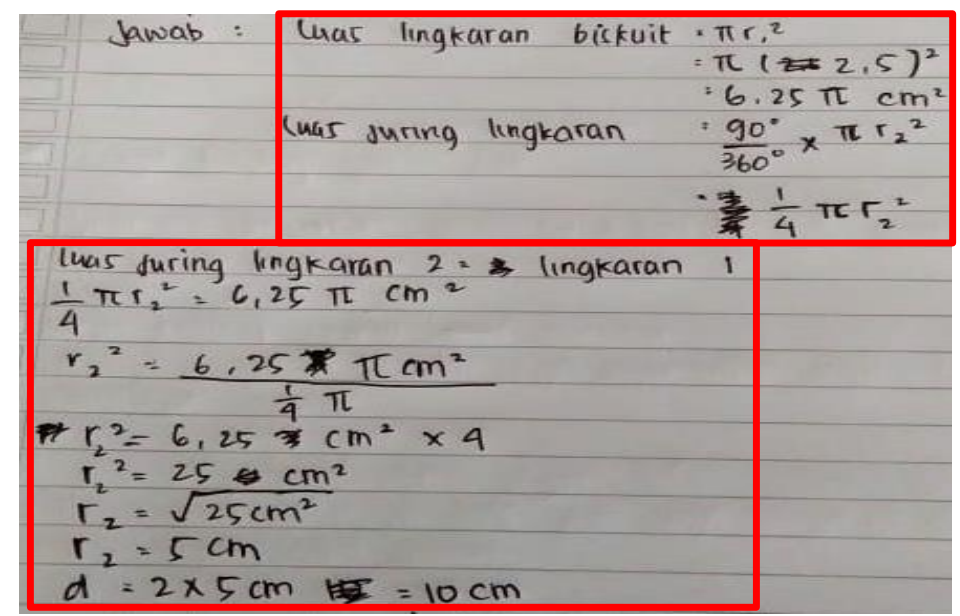

Gambar 7. Komunikasi Matematis SCR dalam Melaksanakan Rencana

SCR kurang memenuhi indikator kemampuan komunikasi matematis tulis yaitu menuliskan langkah-langkah dari rencana yang sudah dibuat untuk menyelesaikan masalah lingkaran dalam bentuk aljabar namun masih ada persamaaan yang salah serta beberapa coretan seperti tampak pada Gambar 7. Kesalahan penulisan persamaan yang dilakukan oleh SCR adalah Luas juring lingkaran 2 = lingkaran 1, yang seharusnya ruas kanan tertulis Luas lingkaran 1. Berdasarkan paparan hasil wawancara, SCR kurang memenuhi indikator kemampuan komunikasi matematis lisan karena SCR tidak menjelaskan secara rinci setiap langkah penyelesaiannya. Ini tampak pada kutipan, "saya mencari luas lingkaran karena biskuit pertama berbentuk lingkaran, yang hasilnya enam koma dua puluh lima phi centimeter kuadrat. Setelah itu saya mencari luas juring untuk biskuit kedua bu, diperoleh hasil seperempat phi $r$ dua kuadrat. Karena jari-jarinya lima centimeter maka diameter untuk biskuit kedua adalah sepuluh centimeter.".

Pada tahap memeriksa kembali, SCR kurang memenuhi indikator kemampuan komunikasi matematis tulis karena kurang lengkap dalam menuliskan hasil pemecahan masalah seperti tampak pada Gambar 8.$$
\text { Jadi di ameter bekuit ke-2 adalah } 10 \mathrm{~cm} \text {. }
$$

Gambar 8. Komunikasi Matematis SCR dalam Memeriksa Kembali Penyelesaian SCR dapat menuliskan hasil dari pemecahan masalah dengan menarik kesimpulan dengan menuliskan pernyataan yang kurang lengkap "Jadi diameter biskuit ke-2 adalah $10 \mathrm{~cm}$ " pada akhir penyelesaian. SCR tidak memberikan kesimpulan lengkap, karena tidak menuliskan pernyataan yang mengandung informasi yang menjadi syarat penyelesaian. Berdasarkan paparan hasil wawancara, SCR kurang memenuhi indikator mampu menjelaskan hasil dan kesimpulan dari pemecahan masalah lingkaran. SCR menjelaskan kesimpulan dari hasil permasalahan tetapi kurang lengkap karena tidak menyebutkan informasi yang menjadi syarat 
penyelesaian seperti pada kutipan wawancara," Jadi, diameter biskuit kedua adalah sepuluh centimeter".

\section{Pembahasan}

SCT memenuhi indikator kemampuan komunikasi matematis secara tulis dan lisan pada tahap memahami circle problem. SCT dapat menghubungkan situasi biskuit pada masalah dengan ide matematika, relasi serta representasi gambar yang menunjukkan lambang lingkaran. Ini sejalan dengan Smieskova (2017) bahwa komunikasi ide matematika membantu siswa untuk memperjelas dan memperkuat pemahaman mereka tentang matematika.

SCT mampu memenuhi indikator komunikasi matematis baik secara tulis dan lisan pada tahap merencanakan dan melaksanakan rencana penyelesaian. SCT dapat menuliskan dan menjelaskan rencana serta tahapan pemecahan masalah yang berkaitan dengan lingkaran dalam bentuk aljabar. Kemampuan komunikasi matematis SCT baik secara tulis maupun lisan dalam merencanakan dan melaksanakan rencana penyelesaian ini berpengaruh pada tahap penyelesaian selanjutnya. Hal ini dikarenakan komunikasi dalam bentuk tertulis dan verbal penting dalam matematika karena meningkatkan kemampuan siswa untuk meningkatkan pemahaman dan kinerja matematika secara keseluruhan (Letwinsky, 2017; Turner, 2011; Wood, Jones, Stover, \& Polly, 2011).

SCT mampu memenuhi indikator kemampuan komunikasi matematis secara tulis dan lisan pada tahap memeriksa kembali penyelesaian. SCT mampu menuliskan dan menjelaskan kesimpulan serta hasil penyelesaian circle problem. SCT mampu mengkomunikasikan penyelesaian di setiap langkah/tahapan penyelesaian menurut Polya. Ini mennunjukkan bahwa komunikasi matematis penting bagi siswa untuk menyampaikan ide, persepsi, dan solusi matematisnya kepada orang lain (Puspita \& Firdaus, 2016). Ini sejalan dengan Rizqi et al. (2016), yang menyatakan jika siswa memiliki kepercayaan diri tinggi maka ia mampu mengungkapkan ide-ide matematis secara lisan dan tulis, koheren dan jelas, ia juga mampu menggambarkan dalam bentuk visual dengan lengkap, mampu menggunakan istilah, notasi, dan struktur matematika dengan tepat. Selain itu, kemampuan komunikasi matematis juga mendukung kemampuan dalam pemecahan masalah (Alhaddad et al., 2015).

Berbeda dengan SCT, SCR kurang memenuhi indikator kemampuan komunikasi matematis secara tulis dan lisan pada tahap memahami circle problem. SCR belum mampu merepresentasikan dalam bentuk gambar apa yang diketahui dan tampak mencoret lambang diameter serta ukurannya, serta kurang lengkap dalam menuliskan/menjelaskan apa yang 
ditanyakan. SCT kurang mampu memenuhi indikator komunikasi matematis tulis tetapi mampu secara lisan pada tahap merencanakan penyelesaian. Hasil ini sejalan dengan pernyataan Noviyana, Dewi, dan Rochmad (2019) yaitu siswa yang kurang memiliki self-confidence, kurang yakin dengan kemampuannya dan kurang berani dalam menyampaikan pendapatnya dalam menyelesaikan soal, termasuk dalam memahami masalah, sehingga berpengaruh pada kemampuan komunikasi matematisnya.

SCR kurang mampu memenuhi indikator kemampuan komunikasi matematis secara tulis dan lisan pada tahap melaksanakan rencana dan memeriksa kembali penyelesaian. SCR menuliskan serta menjelaskan langkah-langkah dan hasil penyelesaian secara kurang lengkap dan kurang rinci. Hal ini didukung dengan pernyataan bahwa kemampuan komunikasi merupakan prasyarat dalam menyelesaikan masalah matematika, jika siswa tidak dapat mengkomunikasikan serta menginterpretasikan konsep dan masalah matematika, maka ia tidak dapat menyelesaikan masalah dengan baik (Alhaddad et al., 2015).

Circle problem merupakan soal matematika yang merupakan tipe $\mathrm{C} 4$ yang perlu kemampuan untuk menganalisis informasi yang dibutuhkan (Hobri, Tussolikha, \& Oktavianingtyas, 2020), yang juga termasuk soal tipe HOTS (Lukitasari, Handhika, \& Murtafiah, 2018). Masalah/soal tipe HOTS dapat digunakan untuk mengukur kualitas kemampuan komunikasi matematis siswa karena melibatkan konteks nyata (Murtafiah, 2009; Widjaja, 2013; Murtafiah, Sa'dijah, Chandra, \& Susiswo, 2020), karena siswa harus menginterpretasikan masalah serta konsep untuk penyelesaiannya. Circle problem juga dapat mengukur komunikasi matematis berdasarkan kepercayaan diri siswa. Dalam menyelesaikan masalah tersebut siswa dituntut untuk memiliki kepercayaan diri dalam menuliskan/menjelaskan ide-idenya untuk penyelesaian masalah (Miri, David, \& Uri, 2007; Surya, Putri, \& Mukhtar, 2017). Siswa mengembangkan rasa percaya diri sebagai pembelajar matematika, sehingga mereka harus menggunakan komunikasi untuk menghasilkan dan berbagi ide (Smieskova, 2017). Melalui circle problem tersebut, siswa dapat memperoleh kemampuan termasuk rasa percaya diri dalam menghadapi situasi yang baru ditemuinya (Martyanti, 2016).

\section{Simpulan}

Kemampuan komunikasi matematis dalam menyelesaikan circle problem berdasarkan self-confidence siswa SMP dapat disimpulkan sebagai berikut: (1) SCT mampu memenuhi sedangkan SCR kurang mampu memenuhi indikator kemampuan komunikasi matematis secara 
tulis dan lisan pada tahap memahami masalah, (2) SCT mampu memenuhi indikator komunikasi matematis secara tulis dan lisan, sedangkan SCR kurang mampu memenuhi indikator komunikasi matematis tulis tetapi mampu secara lisan pada tahap merencanakan penyelesaian, (3) SCT mampu memenuhi sedangkan SCR kurang mampu memenuhi indikator kemampuan komunikasi matematis secara tulis dan lisan pada tahap melaksanakan rencana penyelesaian, (4) SCT mampu memenuhi sedangkan SCR kurang mampu memenuhi indikator kemampuan komunikasi matematis secara tulis dan lisan pada tahap memeriksa kembali penyelesaian. Dengan demikian, rekomendasi yang dapat diberikan adalah pentingnya merancang secara khusus soal/masalah yang sesuai agar dapat melatih kemampuan komunikasi matematis siswa dengan self-confidence rendah.

\section{Referensi}

Agustyaningrum, N., \& Widjajanti, D. B. (2013). Pengaruh pendekatan CTL dengan setting kooperatif tipe kancing gemerincing terhadap kemampuan komunikasi matematis, kepercayaan diri, dan prestasi belajar matematika siswa SMP. Pythagoras: Jurnal Pendidikan Matematika, 8(2), 171-180.

Akbar, S. (2013). Instrumen perangkat pembelajaran. Bandung: PT Remaja Rosdakarya.

Alhaddad, I., Kusumah, Y. S., Sabandar, J., \& Dahlan, J. A. (2015). Enhancing students' communication skills through treffinger teaching model. IndoMS-JME, 6(1), 31-39. https://doi.org/10.22342/jme.6.1.1856.31-39.

Asikin, M., \& Junaedi, I. (2013). Kemampuan komunikasi matematika siswa SMP dalam setting pembelajaran RME (Realistic Mathematics Education). Unnes Journal of Research Mathematics Education, 2(1), 203-213.

Bandura, A. (1994). Self-efficacy. In V. S. Ramachaudran (Ed.), Encyclopedia of Human Behavior, Vol. 4. New York: Academic Press. Retrieved from http://www.des.emory.edu/mfp/BanE ncy.html

Brenner, M. E. (1998letwinsky). Development of mathematical communication in problem solving groups by language minority students. Bilingual Research Journal, 22(2-4), 149174. https://doi.org/10.1080/15235882.1998.10162720.

Budiyono. (2011). Penilaian hasil belajar. Surakarta: Universitas Sebelas Maret.

Hendriana, H. (2014). Membangun kepercayaan diri siswa melalui pembelajaran matematika $\begin{array}{llll}\text { humanis. Jurnal } & \text { Pengajaran }\end{array}$ https://doi.org/10.18269/jpmipa.v19i1.424.

Hobri, Tussolikha, D., \& Oktavianingtyas, E. (2020). Pemecahan masalah dalam menyelesaikan soal jumping task ditinjau dari gaya kognitif. Jurnal Elemen, 6(2), 183198. https://doi.org/10.29408/jel.v6i2.1987.

Lauster, P. (2003). Tes kepribadian (alih bahasa: D.H. Gulo). Jakarta: PT.Bumi Aksara.

Letwinsky, K. M. (2017). Examining the relationship between secondary mathematics teachers' self-efficacy, attitudes, and use of technology to support communication and mathematics literacy. International Journal of Research in Education and Science (IJRES), 3(1), 5666. https://doi.org/10.21890/ijres.267371.

Lie, A. (2003). 101 Cara menumbuhkan percaya diri anak. Jakarta: PT Elex Media Komputindo.

Lukitasari, M., Handhika, J., \& Murtafiah, W. (2018). Higher order thinking skills: Using e- 
portfolio in project-based learning. Journal of Physics, 983, 1-7. https://doi.org/10.1088/1742-6596/983/1/012047.

Majid, A. (2015). Pendekatan ilmiah dalam implementasi kurikulum 2013. Bandung: PT Remaja Rosdakarya.

Martyanti, A. (2016). Keefektifan pendekatan problem solving dengan setting STAD dan TAI ditinjau dari prestasi dan self-confidence. Jurnal Riset Pendidikan Matematika, 3(1), 115. https://doi.org/10.21831/jrpm.v3i1.9825.

Miri, B., David, B. C., \& Uri, Z. (2007). Purposely teaching for the promotion of higher-order thinking skills: A case of critical thinking. Research in Science Education, 37(4), 353369. https://doi.org/10.1007/s11165-006-9029-2.

Murtafiah, W. (2009). Profil kemampuan siswa memecahkan masalah kontekstual matematika di SMPN 1 Madiun. Jurnal Pendidikan MIPA, 1(1), 25-37.

Murtafiah, W. (2016). Kemampuan komunikasi matematika mahasiswa calon guru matematika dalam menyelesaikan masalah persamaan diferensial ditinjau dari gender. Jurnal Math Educator Nusantara, 2(1), 31-41. https://doi.org/10.22236/KALAMATIKA.vol1no2.2016pp171-182.

Murtafiah, W., Sa'dijah, C., Chandra, T. D., \& Susiswo. (2020). Exploring the types of problems task by mathematics teacher to develop students' HOTS. In AIP Conference Proceedings 2215, 060018. https://doi.org/10.1063/5.0000656.

NCTM. (2000). Six principles for school mathematics. In National Council of Teachers of Mathematics (pp. 1-6). Retrieved from http://www.nctm.org/uploadedFiles/Math_Standards/12752_exec_pssm.pdf

Nganga, L. (2019). Preservice teachers' perceptions and preparedness to teach for global mindedness and social justice using collaboration, critical thinking, creativity and communication (4cs). Journal of Social Studies Education Research, 10(4), 26-57.

Noviyana, I. N., Dewi, N. R., \& Rochmad. (2019). Analisis kemampuan komunikasi matematis siswa ditinjau dari kemampuan matematika siswa. PRISMA, Prosiding Seminar Nasional Matematika, 704-709. https://doi.org/10.30738/.v6i2.2213.

Nurkholifah, S., Toheri, \& Winarso, W. (2018). Hubungan antara self confidence dengan kemampuan berpikir kritis siswa dalam pembelajaran matematika. Pendidikan Matematika, 8(01), 58-66.

Nurlaila, S., Sariningsih, R., \& Maya, R. (2018). Analisis kemampuan komunikasi matematis siswa SMP terhadap soal-soal bangun ruang sisi datar. JPMI (Jurnal Pembelajaran Matematika Inovatif), 1(6), 1113-1120. https://doi.org/10.22460/jpmi.v1i6.p1113-1120.

Polya, G. (1973). How to solve it: A new aspect of mathematical method (second). Princeton, New Jersey: Princeton University Press.

Puspita, H., \& Firdaus, E. (2016). Analysis of mathematical communication skills students in mathematics education at study course junior high school mathematics. International Conference on Education (IECO) Proceeding, 1(7), 344-351.

Ragatz, A. (2010). Di dalam ruang kelas matematika di Indonesia: studi video TIMSS tentang praktek mengajar dan capaian siswa. World Bank, 1-4.

Ramadhan, I., \& Minarti, E. D. (2018). Kajian kemampuan komunikasi matematik siswa SMP dalam menyelesaikan soal lingkaran. Journal of Mathematics Education IKIP Veteran Semarang, 2(2), 151-161. https://doi.org/10.31331/medives.v2i2.624.

Rizqi, A. A., Suyitno, H., \& Sudarmin. (2016). Analisis kemampuan komunikasi matematis ditinjau dari kepercayaan diri siswa melalui blended learning. Unnes Journal of Mathematics Education Research, 5(1), 17-23.

Scott, C. L. (2015). What kind of learning for the 21st century? Education Research and Foresight, United Nations Educational, Scientific and Cultural Organization (UNESCO). Smieskova, E. (2017). Communication students' skills as a tool of development creativity and 
motivation in geometry. Universal Journal of Educational Research, 5(1), 31-35. https://doi.org/10.13189/ujer.2017.050104.

Sugiyono. (2013). Metode penelitian pendidikan (pendekatan kuantitatif, kualitatif, dan $R \& D)$. Bandung: Alfabeta.

Sumarna, S. (2009). Analisis, validitas, reliabilitas, dan interpretasi hasil tes implementasi kurikulum 2004. Bandung: PT Remaja Rosdakarya.

Surya, E., Putri, F. A., \& Mukhtar. (2017). Improving mathematical problem-solving ability and self-confidence of high school students through contextual learning model. Journal on Mathematics Education, 8(1), 85-94. https://doi.org/10.22342/jme.8.1.3324.85-94.

Turner, R. (2011). Identifying cognitive processes important to mathematics learning but often overlooked. Australian Mathematics Teacher, 76(2), 22-26.

Umar, W. (2012). Membangun kemampuan komunikasi matematis dalam pembelajaran matematika. Infinity Journal, 1(1), 1-9. https://doi.org/10.22460/infinity.v1i1.2.

Vale, I., \& Barbosa, A. (2017). The importance of seeing in mathematics communication. European Teacher Education Network, 12, 49-63.

Voogt, J., \& Roblin, N. P. (2012). A comparative analysis of international frameworks for 21 st century competences: implications for national curriculum policies. Journal of Curriculum Studies, 44(3), 299-321. https://doi.org/10.1080/00220272.2012.668938.

Widjaja, W. (2013). The use of contextual problems to support mathematical learning. Journal on Mathematics Education, 4(2), 151-159. https://doi.org/10.22342/jme.4.2.413.151$\underline{159}$.

Wood, K., Jones, J., Stover, K., \& Polly, D. (2011). STEM literacies: Integrating reading, writing, and technology in science and mathematics. Middle School Journal, 43(1), 5562. https://doi.org/10.1080/00940771.2011.11461794. 